University of Rhode Island

DigitalCommons@URI

The Rhode Island Current Conditions Index

Economics

$12-2013$

\title{
Rhode Island Current Conditions Index - December 2013
}

Leonard Lardaro

University of Rhode Island, lardaro@uri.edu

Follow this and additional works at: https://digitalcommons.uri.edu/ricci

Part of the Econometrics Commons

Terms of Use

All rights reserved under copyright.

\section{Recommended Citation}

Lardaro, Leonard, "Rhode Island Current Conditions Index -- December 2013" (2013). The Rhode Island Current Conditions Index. Paper 94.

https://digitalcommons.uri.edu/ricci/94

This Article is brought to you for free and open access by the Economics at DigitalCommons@URI. It has been accepted for inclusion in The Rhode Island Current Conditions Index by an authorized administrator of DigitalCommons@URI.For more information, please contact digitalcommons-group@uri.edu. 


\title{
CURRENT CONDITIONS
}

LEONARD LARDARO, URI

\author{
Available Online: http:/ / www .llardaro.com/ current.htm \\ Blog: http:/ / rieconomy.blogspot.com
}

VOL XXI

NUMBER 1

DEC 2013

As the fourth quarter and 2013 came to an end, Rhode Island's economic performance continued as it had for a while - we are moving forward, albeit at a not very encouraging speed. The news overall continued to be mixed: the good news was that the Current Conditions Index for December rose slightly to 75 from its November value of 67 . And, within December's performance, there were some positive results, mainly that almost all of the $\mathrm{CCl}$ 's leading economic indicators improved. That bodes well as we move into 2014. The bad news pertains to the continuation of a disturbing pattern: for a fifth consecutive month, and the sixth time in seven months, the $\mathrm{CCl}$ failed to exceed its year-earlier value. Hopefully, since the $\mathrm{CCl}$ values in early 2013 were not as strong as they had been in late 2012, we will soon find ourselves exceeding year-earlier values again in the first part of 2014. That is a very real possibility if the US economy continues to strengthen. We'll just have to keep our fingers crossed. Once we begin to exceed prior-year values this will be the signal that the recovery is once again becoming more broadly based and that our momentum is accelerating. As I noted last month, the ultimate test of how robust Rhode Island's recovery proves to be will be defined by our ability to accelerate from current and past rates of growth. We can only hope that our state's continuing failure to meaningfully redefine itself for the information age (other than renaming the EDC) won't pose too many obstacles.

For December, four of the $\mathrm{CCl}$ 's five leading indicators improved. The other, Single-Unit Permits, barely failed to improve declining 1.4 percent from a year ago. While this was only its third non-improvement in over a year, this month's result may well be more of a reflection of December's weather than of any underlying economic weakness in our state's housing sector

\begin{tabular}{|l|r|r|}
\hline \multicolumn{3}{|c|}{ CCI Indicators - \% Change } \\
\hline Government Employment & $-\mathbf{0 . 3}$ & \\
\hline US Consumer Sentiment & $\mathbf{1 2 . 9}$ & $\mathbf{Y}$ \\
\hline Single-Unit Permits & $-\mathbf{1 . 4}$ & \\
\hline Retail Sales & 2.1 & $\mathbf{Y}$ \\
\hline Employment Services Jobs & $\mathbf{2 . 0}$ & $\mathbf{Y}$ \\
\hline Priv. Serv-Prod Employment & $\mathbf{0 . 8}$ & $\mathbf{Y}$ \\
\hline Total Manufacturing Hours & 3.5 & $\mathbf{Y}$ \\
\hline Manufacturing Wage & $\mathbf{4 . 3}$ & $\mathbf{Y}$ \\
\hline Labor Force & $-\mathbf{2 . 3}$ & \\
\hline Benefit Exhaustions & $-\mathbf{1 8 . 2}$ & $\mathbf{Y}$ \\
\hline New Claims & $-\mathbf{2 1 . 8}$ & $\mathbf{Y}$ \\
\hline Unemployment Rate (change) & $-\mathbf{0 . 8}$ & $\mathbf{Y}$ \\
\hline \multicolumn{2}{|c|}{ Y = Improved Value } \\
\hline
\end{tabular}

US Consumer Sentiment rose sharply $(+12.9 \%)$ in December following three consecutive months of declines. It has remained in an uptrend that we can expect to continue as long as the stock market continues to improve. Employment Service Jobs, which includes temporary employment, a prerequisite to overall employment growth, rose by 2.0 percent in December following a decline last month. While it remains in an uptrend, it appears quite likely that its values are levelling off around 9,000, assuming that rebenchmarking next month doesn't change this pattern. Should layoffs begin to rise, this will pose a number of problems to our economic momentum as we move into 2014.

All of the remaining leading indicators improved in December. New Claims for Unemployment Insurance, the timeliest measure of layoffs, improved significantly in December, falling by 21.8 percent, its second consecutive double-digit decline. While this indicator is not yet in a well-defined downtrend, the most recent four months indicate that this may be changing. The final leading indicator, Total Manufacturing Hours, which measures strength in our manufacturing sector, rose by a very healthy 3.5 percent in December, driven mainly by a large increase in the length of the workweek. This indicator has now improved for eleven of the last thirteen months. Combined with the recent behavior of Single-Unit Permits, it is clear that Rhode Island's goods-producing sector is far from dead.

Retail Sales have remained strong on a year-over-year basis, in spite of a slowing in their rate of growth of late. On a monthly basis, however, Retail Sales have generally been declining since September. Private Service-Producing Employment growth, which had recently moved above a one percent rate of growth, slipped below that rate in December, rising by only 0.8 percent. When the rebenchmarked data are released next month, we will likely see notable revisions in this indicator. Our state's Labor Force declined yet again (for the ninth consecutive time). Yet in spite of this, Rhode Island managed to move into sole possession of the \#1 slot, not for a noteworthy positive area, but for our Unemployment Rate. Rhode Island's jobless rate rose slightly over the month while other states saw declining rates. Finally, Government Employment edged down again (by $0.3 \%$ ).

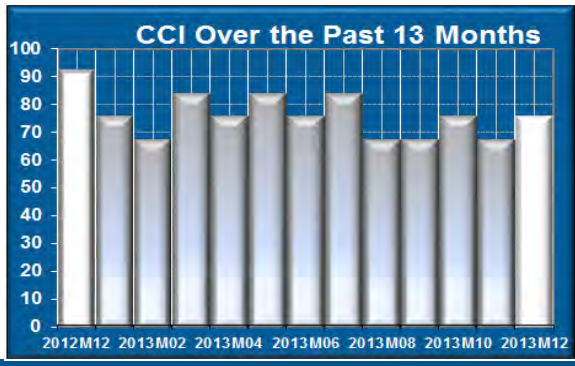

DLT DEC Employment (SA, Y/Y)

Gain

5,600

Loss

2,000

\section{THE BOTTOM LINE}

The fourth quarter ended on a far less positive note than what we experienced one year ago. At present, Rhode Island's economy has moved beyond an inflection point in terms of its rate of growth, as our state's recovery has now become somewhat less broadly based. Evidence of this is provided by the fact that the $\mathrm{CCl}$ has now failed to exceed its year-earlier value for five consecutive months, hardly a very happy way to end the year! In spite of this, pockets of positive momentum exist, perhaps more than one might think, but not as much as we should have been experiencing had our elected officials done the hard work of meaningfully reinventing our state's economy.

\begin{tabular}{c|c|c|c|c|c|c|c|c|c|c|c|c|c|} 
& & Jan & Feb & Mar & Apr & May & J un & Jul & Aug & Sep & Oct & Nov & Dec \\
\hline \multirow{2}{*}{2012} & $67 \uparrow$ & $58 \uparrow$ & 58 & $67 \uparrow$ & $67 \uparrow$ & $83 \uparrow$ & $58 \uparrow$ & $92 \uparrow$ & $75 \uparrow$ & $92 \uparrow$ & $83 \uparrow$ & $83 \downarrow$ \\
\cline { 2 - 12 } & 2013 & 75 & 67 & 83 & $75 \uparrow$ & 83 & 75 & $83 \uparrow$ & 67 & $67 \downarrow$ & 75 & 67 & 75 \\
\hline
\end{tabular}

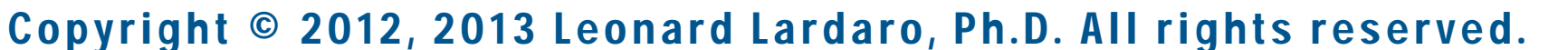

